\title{
12S Mitochondrial Ribosomal RNA
}

National Cancer Institute

\section{Source}

National Cancer Institute. 125 Mitochondrial Ribosomal RNA. NCI Thesaurus. Code C128263.

$12 \mathrm{~S}$ mitochondrial ribosomal RNA is encoded by the human MT-RNR1 gene. This ribonucleotide is involved in mitochondrial protein translation. 